\title{
Synthesis of ZnO/ECB (Eichhornia crassipes Biochar) as a Sustainable Efficient Photocatalyst for Photodegradation of Reactive Black-5
}

\author{
M. Mulyatun ${ }^{1, *}$ Wirda Udaibah ${ }^{1}$ Siti Hafidzotur ${ }^{1}$ Hamdan Hadi Kusuma ${ }^{2}$ \\ ${ }^{1}$ Department of Chemistry, Universitas Islam Negeri Walisongo Semarang, Indonesia \\ ${ }^{2}$ Department of Physics, Universitas Islam Negeri Walisongo Semarang, Indonesia \\ *Corresponding author. Email: mulyatun@walisongo.ac.id
}

\begin{abstract}
$\mathrm{ZnO} / \mathrm{ECB}$ photocatalyst (Eichhornia crassipes Biochar) has been synthesized to be applied as a photocatalyst in the degradation of Reactive Black-5 dye. $\mathrm{ZnO} / \mathrm{ECB}$ photocatalyst was synthesized by the coprecipitation method with the ratio $\mathrm{Zn}\left(\mathrm{NO}_{3}\right)_{2} .6 \mathrm{H}_{2} \mathrm{O}: \mathrm{ECB}$ (M:w) $0.25: 1 \quad(0.25 \mathrm{MZnO} / \mathrm{ECB}) ; 0.45: 1 \quad(0.45 \mathrm{MZnO} / \mathrm{ECB})$; and $0.6 ; 1$ (0.6 $\mathrm{MZnO} / \mathrm{ECB})$. The characteristics of the $\mathrm{ZnO} / \mathrm{ECB}$ photocatalyst were tested using $\mathrm{X}$-ray diffraction, Fourier Transforms Infrared (FTIR), and UV Diffuse Reflectance Spectroscopy (UV-DRS) to determine the energy gap of the photocatalyst. The diffractogram pattern showed that the $\mathrm{ZnO} / \mathrm{ECB}$ crystals were hexagonal wurtzite in shape. The results of the Kubelka-Munk UV-DRS analysis showed that the energy gap of the ZnO/ECB photocatalyst was smaller than that of pure $\mathrm{ZnO}$. The efficiency of the $\mathrm{ZnO} / \mathrm{ECB}$ catalyst was evaluated through photocatalytic degradation of an aqueous solution of Reactive Black-5 dye. Measurement of photocatalytic activity under $\mathrm{UV}$ radiation showed that $\mathrm{ZnO} / \mathrm{ECB}$ photocatalyst has a higher degradation ability than pure $\mathrm{ZnO}$. The high photocatalytic activity of the $\mathrm{ZnO} / \mathrm{ECB}$ catalyst was due to the low energy gap of the $\mathrm{ZnO} / \mathrm{ECB}$ catalyst, thereby reducing the electron and hole recombination rate in the synthesized photocatalyst. Photocatalyst of ${ }_{0.25} \mathrm{ZnO} / \mathrm{ECB}$ has the highest photocatalytic activity with degradation efficiency reaching $75.47 \%$ -
\end{abstract}

\section{Keywords: Photocatalyst, ZnO, Eichhornia crassipes, Biochar, Reactive Black-5}

\section{INTRODUCTION}

Reactive Black-5 is the largest type of azo dye commonly used for the textile industry up to $70 \%$ [1], [2]. Reactive Black-5 is widely used because it has several advantages such as fadeproof, bright colors, and easy coloring application [3-5]. Reactive Black-5 is carcinogenic, toxic, and mutagenic. it has a stable aromatic amine group, this causes high stability against biological degradation in water [6]. Disposal of Reactive Black-5 into the environment poses a major threat to public health because exposure to dyes causes respiratory system disorders, acute bronchitis, skin irritation, mutations, and bladder cancer [7].

Reactive Black-5 dye waste treatment is a complex and expensive process because the dye consists of a stable complex aromatic structure [8]. Efforts to deal with conventional dyestuffs such as adsorption using activated carbon have been carried out, but the results are less effective because they produce secondary dye pollution [9]. Modern methods that have been developed to deal with this dye waste include biodegradation, chlorination, and ozonation methods [10]. This method gives satisfactory results, but the operational cost of this method is quite expensive. For this reason, it is necessary to develop a dye wastewater treatment technology that is environmentally friendly, easy, inexpensive, and has maximum results.

Advanced oxidation process (AOP) such as photocatalysis using heterogeneous catalysts is one of the preferred textile wastewater treatment techniques for the degradation of dye contaminants [11]. This is because chemical oxidation is an efficient, inexpensive and environmentally friendly process [12]. The photocatalytic system does not produce secondary pollutants, this is because all organic dye pollutants are converted into carbon dioxide $\left(\mathrm{CO}_{2}\right)$, water $\left(\mathrm{H}_{2} \mathrm{O}\right)$ and inorganic ions [13]. The photocatalytic process is a promising, efficient, environmentally friendly process for the removal of toxic pollutants and dye degradation 
[14]. Some semiconductors that are often used as photocatalysts are $\mathrm{ZnO}, \mathrm{TiO}_{2}, \mathrm{CdS}, \mathrm{Ag}_{3} \mathrm{PO}_{4}$ [15].

$\mathrm{ZnO}$ is a semiconductor that has high electron mobility, has good thermal stability, high photosensitivity, and is a very potential photocatalyst [14]. $\mathrm{ZnO}$ is an inexpensive alternative photocatalyst used for the degradation of organic dyes contained in textile industrial waste[15]. $\mathrm{ZnO}$ also has a weakness, namely the gab energy is quite large $(3.3 \mathrm{eV})$ which allows fast electron-hole recombination so that it reduces the photodegradation ability of $\mathrm{ZnO}$. To overcome this limitation, several researchers have investigated intensively by adding $\mathrm{ZnO}$ to suitable buffer materials such as zeolite, biochar or doping with metal ions [16].

One of the modifications of $\mathrm{ZnO}$ to increase its photodegradation ability is to add biochar as a buffer material. Biochar is an electron acceptor so that it can carry electrons on the surface of the $\mathrm{ZnO}$ semiconductor to electron-holes in the conduction band [17]. The combination of $\mathrm{ZnO}$ and biochar can reduce the energy gap in the $\mathrm{ZnO}$ photocatalyst and prevent electron-hole recombination recombination. Biochar is a carbon-rich product produced from the thermal decomposition of biomass such as wood, leaves, agricultural waste, and solid waste, with very limited oxygen conditions at low temperatures [20, 21].

One of the potential materials to be used as biochar is Eichornia crassipes [20]. Eichornia crassipes is a source of cellulose-rich biomass which contains $18.2 \%$ cellulose, $48.70 \%$ hemicellulose, $3.5 \%$ lignin, and $13.3 \%$ protein which has the potential as biochar [21]. Eichornia crassipes Biochar (ECB) is a potential material as a buffer for $\mathrm{ZnO}$ because it can increase its photocatalytic efficiency. The combination of $\mathrm{ZnO}$ with Eichhornia crassipes Biochar is expected to reduce the energy gap of the photocatalyst and prevent electron-hole recombination which further increases the photodegradation efficiency of Reactive Black-5 dye.

\section{METHODOLOGY}

\subsection{Materials}

The materials used were water hyacinth stems, $\mathrm{H}_{3} \mathrm{PO}_{4} 80 \%$ (Sigma-Aldrich), $\mathrm{Zn}\left(\mathrm{NO}_{3}\right)_{2} \cdot 6 \mathrm{H}_{2} \mathrm{O} 99 \%$ (Sigma Aldrich), $\mathrm{NaOH}$ 98\% (Merck), Ethanol (Merck), $\mathrm{HCl}$ (Merck), Methyl red, and distilled water. The tools used are 80 mesh sieve, magnetic stirrer, oven, furnace, $\mathrm{pH}$ meter and analytical balance.
Instruments used include: XRD, FTIR, UV-DRS, UVVis.

\subsection{Preparation and modification of biochars}

Synthesis of Eichhornia crassipes biochar was carried out using the Hydrothermal method. The stems of Eichornia crassipes are cut into small pieces, dried in the sun. Water hyacinth stems were dried in an oven at $105^{\circ} \mathrm{C}$ for 24 hours. The dried Eichornia crassipes stems was crushed to 0.5 um (Danish et al., 2018). 30 grams of dry Eichornia crassipes stems were mixed with $200 \mathrm{~mL}$ of deionized water in an autoclave reactor. The reactor was heated in a furnace with a hydrolysis temperature of 240 for 3 hours [18]. The reactor was cooled, then the biochar product was rinsed with deionized water and dried in an oven at $80^{\circ} \mathrm{C}$. A total of 20 grams of Biochar is activated in $80 \mathrm{ml}$ $\mathrm{H}_{3} \mathrm{PO}_{4} 80 \%$. The mixture was stirred using a magnetic stirrer at $85^{\circ} \mathrm{C}$ for 4 hours [22]. The activated biochar was washed using distilled water until the $\mathrm{pH}$ is neutral. Eichornia crassipes Biochar (ECB) was then dried in an oven at $105^{\circ} \mathrm{C}$ for 24 hours [23]. The activated biochar was then calcined at $450^{\circ} \mathrm{C}$ for 120 minutes.

Synthesis of $\mathrm{ZnO} / \mathrm{ECB}$ photocatalyst using coprecipitation method. $\mathrm{Zn}\left(\mathrm{NO}_{3}\right)_{2} \cdot 6 \mathrm{H}_{2} \mathrm{O}$ solution as $\mathrm{ZnO}$ precursor. $\mathrm{ZnO} / \mathrm{ECB}$ (Eichornia crassipes Biochar) photocatalyst was synthesized using 1 gram of ECB (Eichornia crassipes Biochar) with concentration variations of $\mathrm{ZnO}$ in $0.25 \mathrm{M} ; 0.45 \mathrm{M}$; and $0.6 \mathrm{M}$. As much as 1 gram of ECB (Eichornia crassipes Biochar) was added each in $100 \mathrm{ml}$ of $\mathrm{Zn}\left(\mathrm{NO}_{3}\right)_{2} .6 \mathrm{H}_{2} \mathrm{O}$ solution $0.25 \mathrm{M} ; 0.45 \mathrm{M}$; and $0.6 \mathrm{M}$. The mixture was heated and stirred with a magnetic stirrer at $90^{\circ} \mathrm{C}$ for 1 hour. $100 \mathrm{ml}$ of $1 \mathrm{M} \mathrm{NaOH}$ solution was added to the mixture and stirred again for 3 hours. The solution was centrifuged at $4000 \mathrm{rpm}$. The precipitate was washed with hot water and ethanol. The solids were then calcined at $350^{\circ} \mathrm{C}$ for 3 hours [24].

\subsection{Characterization of photocatalyst}

The $\mathrm{ZnO} / \mathrm{ECB}$ photocatalyst (Eichornia crassipes Biochar) was characterized using an X-ray diffraction instrument to identify the crystal phase and crystallinity level with $\mathrm{Cu} \mathrm{K} \alpha$ radiation of $1.54056 \AA$ at $40 \mathrm{kV}$ and $20 \mathrm{~mA}, 2 \theta: 10-80^{\circ}$ with a scan rate of $20 / \mathrm{min}$. The average crystal size of the $\mathrm{ZnO} / \mathrm{ECB}$ photocatalyst was calculated by the Scherrer Equation (1). 


$$
D=\frac{K \lambda}{\beta \cos \theta}
$$

Where $\mathrm{D}=$ crystal size, $\mathrm{K}=$ Scherrer constant $(0.9$ to 1$), \lambda=x$-ray wavelength used $(0.15406 \mathrm{~nm}), \beta=$ peak width, and $\theta=$ peak angular position. Functional group vibrations are shown in the infrared spectrum which was analyzed using FTIR with a resolution of $4 \mathrm{~cm}^{-1}$ in the $4000-400 \mathrm{~cm}^{-1}$ wave region. The energy gap of the $\mathrm{ZnO} / \mathrm{ECB}$ photocatalyst was analyzed in the UVVis wavelength region of 200-800 $\mathrm{nm}$ using a UVDRS spectrophotometer. The amount of energy gab can be calculated through Equation 2:

$E=\frac{h c}{\lambda}=\frac{1240}{\lambda} e V$

\subsection{Photocatalytic Activity Testing of}

\section{ZnO/ECB (Eichornia crassipes Biochar)}

Photocatalytic activity tests were carried out on samples of $\mathrm{ZnO}, \mathrm{ECB}$, and $\mathrm{ZnO} / \mathrm{ECB}$ to degrade Reactive Black-5 dye using a UV lamp. Photodegradation of Reactive Black-5 was carried out by adding photocatalyst to Reactive Black-5 solution. The mixed solution was put into a UV reactor and irradiated using a mercury lamp (UV-A lamp, Sankyo denki F20T10BLB, $\lambda$ : $352 \mathrm{~nm}$ ) with stirring using a magnetic stirrer. The irradiated Reactive Black-5 solution was measured for its absorbance at the maximum wavelength $(600 \mathrm{~nm})$ using a UV-Vis spectrophotometer. The degradation efficiency $(\xi)$ of Reactive Black-5 is calculated by Equation 3 [25]:

$\xi=\frac{\left(A_{0}-A_{t}\right)}{A_{0}} \times 100 \%$

Where $A_{0}$ is initial absorbance and $A_{\mathrm{t}}$ is final absorbance after UV irradiation.

\section{RESULT AND DISCUSSION}

The $\mathrm{ZnO} / \mathrm{ECB}$ photocatalyst was analyzed using an X-Ray Diffraction instrument to determine the diffraction pattern formed. The diffraction patterns of the $\mathrm{ZnO}$ and $\mathrm{ZnO} / \mathrm{ECB}$ photocatalysts obtained from the analysis were compared with the JCPDS No. 361451. The diffraction patterns of $\mathrm{ZnO}$ and $\mathrm{ZnO} / \mathrm{ECB}$ photocatalysts are shown in Figure 1.

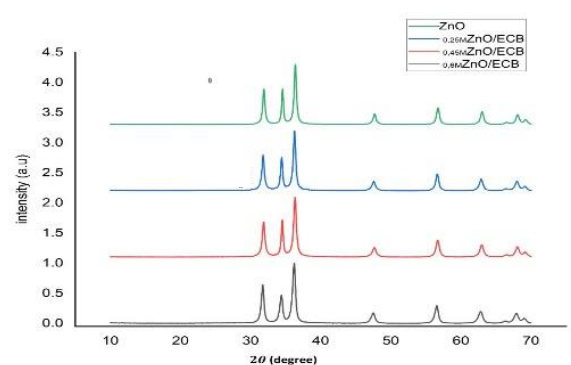

Figure 1 Difractograms of ECB sample $\mathrm{ZnO}$ and $\mathrm{XZnO} / \mathrm{ECB}$ photocatalysts

The X-ray diffraction pattern for the $\mathrm{ZnO}$ and and $X \mathrm{ZnO} / \mathrm{ECB}$ samples $(X=0.25,0.4,0.6)$ is shown in Figure 1 . The $X$-ray diffraction pattern is produced at $2 \theta=5-50^{\circ} \mathrm{ZnO}$ and $\mathrm{XZnO} / \mathrm{ECB}$ samples have similar $\mathrm{X}$-ray diffraction patterns. All samples have quite high peak intensities at $2 \theta=31,89^{\circ} ; 34,56^{\circ} ; 36,38^{\circ} ; 47,67$ ${ }^{\circ}$; 56,72 ${ }^{\circ} ; 63,01^{\circ}$; $66,51^{\circ} ; 68,08^{\circ}$ and $69,20^{\circ}$ which denote hkl diffraction planes (llll $\left.\begin{array}{lll}0 & 0\end{array}\right),\left(\begin{array}{lll}0 & 0 & 2\end{array}\right),\left(\begin{array}{lll}1 & 0 & 1\end{array}\right),\left(\begin{array}{l}1 \\ 1\end{array}\right.$ $\left.\begin{array}{l}0 \\ 0\end{array}\right),\left(\begin{array}{lll}1 & 1 & 0\end{array}\right),\left(\begin{array}{lll}1 & 0 & 3\end{array}\right),\left(\begin{array}{lll}2 & 0 & 0\end{array}\right),\left(\begin{array}{lll}1 & 1 & 2\end{array}\right),\left(\begin{array}{lll}2 & 0 & 1\end{array}\right)$. These peaks are typical peaks of $\mathrm{ZnO}$ with a hexagonal crystal structure [26]. These peaks are in accordance with the Powder Diffraction File (PDF) obtained from the Data Base Joint Committee on Powder Diffraction Standards (JCPDS) with PDF serial number PDF 361451 which has a hexagonal wurtzite structure [29, 30].

Based on the analysis of the diffractogram data of the $\mathrm{ZnO}$ and $X \mathrm{ZnO} / \mathrm{ECB}$ photocatalyst samples, the average crystal size of the $\mathrm{ZnO}$ and $X \mathrm{ZnO} / \mathrm{ECB}$ photocatalyst samples was obtained by calculating the Scherrer equation. The average size of $\mathrm{ZnO}$ and $X \mathrm{ZnO} / \mathrm{ECB}$ crystals is shown in table 1 .

Table 1. Average Crystal Size of $\mathrm{ZnO}$ and $\mathrm{XZnO} / \mathrm{ECB}$

\begin{tabular}{lc}
\hline \multicolumn{1}{c}{ Sample } & $\begin{array}{c}\text { Average Average } \\
\text { crystal size }( \pm \mathbf{0 . 1}(\mathbf{n m}))\end{array}$ \\
\hline $\mathrm{ZnO}$ & 21.84 \\
${ }_{0.25} \mathrm{ZnO} / \mathrm{ECB}$ & 20.07 \\
${ }_{0.45} \mathrm{ZnO} / \mathrm{ECB}$ & 19.23 \\
${ }_{0.6} \mathrm{ZnO} / \mathrm{ECB}$ & 17.23
\end{tabular}

Table 1 show the average size of the $\mathrm{ZnO}$ crystals and the $\mathrm{ZnO} / \mathrm{ECB}$ photocatalyst. The average size of $\mathrm{ZnO}$ crystals and the $\mathrm{ZnO} / \mathrm{ECB}$ photocatalyst decrease as the $\mathrm{ZnO}$ concentration increased. $\mathrm{ZnO}$ crystals bonded to ECB will adjust to a smaller pore size of ECB. As the crystal size decreases, the surface area increases so that the adsorption power is greater due to the increase in the active site of $\mathrm{ZnO}$ bound to carbon. Chen et al. [29] reported that the addition of AC reduced the average particle size of $\mathrm{ZnO}$ particles from 
$27.4 \mathrm{~nm}$ to $12.9 \mathrm{~nm}$ and $11.8 \mathrm{~nm}$. Nano $\mathrm{ZnO}$ is easily agglomerated due to its large specific surface area and high surface energy, and the agglomeration tendency can be weaken by adding AC. However, the addition of too many nanoparticles to activated carbon can reduce the surface area of the material due to the aggregation of nanoparticles on activated carbon due to the closed pores and carbon surface [31, 32].

Functional group vibrations and bonds formed in the sample, $\mathrm{ZnO}, \mathrm{ECB}$ and photocatalyst $\mathrm{XZnO} / \mathrm{ECB}$ were analyzed using the FTIR (Fourier Transform Infrared) instrument. The results of the sample spectra are shown in Figure 2.

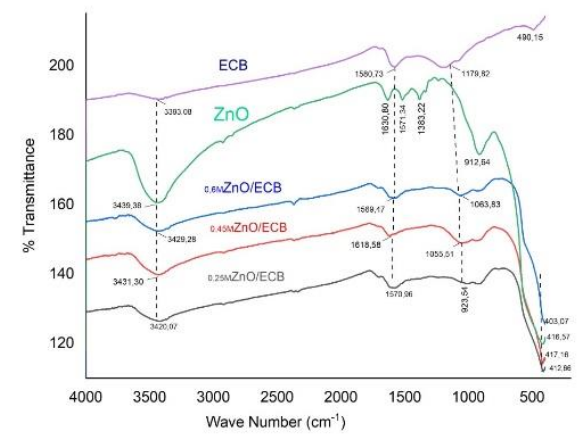

Figure $2 \mathrm{ZnO}, \mathrm{ECB}$, and $\mathrm{XZnO} / \mathrm{ECB}$ Photocatalysts FTIR Spectra

The ECB sample shows a sloping peak at wavelength $3393.08 \mathrm{~cm}^{-1}$ which indicates the stretching of the hydroxyl group $(-\mathrm{O}-\mathrm{H})$ of the water molecule [32]. The peak at wavelength $1580.73 \mathrm{~cm}^{-1}$ indicates stretching of the $\mathrm{C}=\mathrm{C}$ group originating from the aromatic ring on lignin [33]. The peak at wavelength $1179.82 \mathrm{~cm}^{-1}$ shows stretching of the $\mathrm{P}=\mathrm{O}$ and $\mathrm{O}-\mathrm{C}$ groups in the $\mathrm{P}-\mathrm{O}-\mathrm{C}$ bonds of the aromatic ring [33]. The phosphate group may be derived from the Biochar activator in the form of a solution. The peak at wavelength $490.15 \mathrm{~cm}^{-1}$ indicates stretching of the $\mathrm{C}-\mathrm{C}$ of the aromatic ring [34]. The peaks formed in $\mathrm{ZnO}$ crystals and photocatalyst $\mathrm{XZnO} / \mathrm{ECB}$ did not show a significant difference. In $\mathrm{ZnO}$ crystals, a peak of wavelength $3439.38 \mathrm{~cm}^{-1}$ shows the stretching vibration of the hydroxyl group $(-\mathrm{OH})$ of water molecules [35], and peaks at $1630.80 \mathrm{~cm}^{-1}$ and 1571,34 $\mathrm{cm}^{-1}$ indicate bending of the $\mathrm{H}-\mathrm{O}-\mathrm{H}$ group [36, 37 ]. At the peak of $1383.22 \mathrm{~cm}^{-1}$ that formed which shows vibrations of $\mathrm{NO}_{3}$ originating from $\mathrm{Zn}-\mathrm{NO}_{3}$ [36]. The peak at wavelength $912.64 \mathrm{~cm}^{-1}$ indicates the frequency of vibration by charge in the $\mathrm{ZnO}$ microstructure, and the peak at $416.57 \mathrm{~cm}^{-1}$ indicates stretching of $\mathrm{Zn}-\mathrm{O}$, where the peak energy range of $\mathrm{ZnO}$ is in the wavelength range of $400-500 \mathrm{~cm}^{-1}$ [37].
The energy gap of $\mathrm{ZnO}, \mathrm{ECB}$, and $\mathrm{XZnO} / \mathrm{ECB}$ photocatalyst samples was determined using UV Diffuse Reflectance Spectroscopy (UV-DRS). The energy gaps of $\mathrm{ZnO}, \mathrm{ECB}$, and $\mathrm{XZnO} / \mathrm{ECB}$ samples were analyzed in the UV-Vis wavelength region of 200-800 nm. The UV-DRS data spectrum was processed using the Kubelka-Munk equation and then made into a curve that shows the relationship between wavelength and the Kubelka-Munk factor $(F(R))$. F(R) is the $\mathrm{K} / \mathrm{S}$ value where $\mathrm{K} / \mathrm{S}$ is the light adsorption coefficient of the sample. The relationship between the wavelength and the Kubelka-Munk factor is shown in Figure 3.

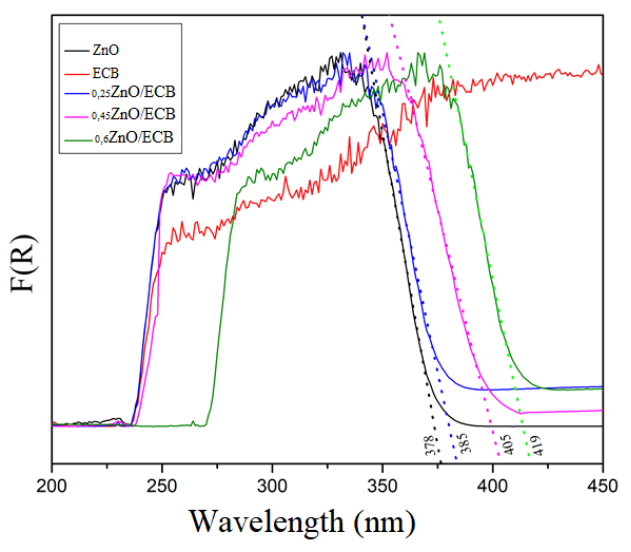

Figure 3 Kubelka-Munk function vs. wavelength for $\mathrm{ZnO}, \mathrm{ECB}$, and $\mathrm{XZnO} / \mathrm{ECB}$ Photocatalysts.

Based on Figure 3, the Kubelka-Munk factor in the ECB sample is increasing towards a larger wavelength region. This proves that the ECB sample does not have a specific absorption at the wavelength of UV light and visible light. Kubelka-Munk factor $\mathrm{ZnO}$ photocatalyst has a high absorption intensity in the UV light region and decreases significantly in the visible light region. In the $\mathrm{ZnO} / \mathrm{ECB}$ photocatalyst, the increase in the absorption of the Kubelka-Munk factor shifted from the $300 \mathrm{~nm}$ wavelength range to the $400 \mathrm{~nm}$ wavelength as the $\mathrm{ZnO}$ concentration increased in the ECB. This shows that with the increasing concentration of $\mathrm{ZnO}$ added to biochar, the light absorption shifts more from the UV light region to the visible light region. Mian \& Liu (2018) stated that carbon material can make photocatalysts with large band gaps more sensitive to light so that the light sensitivity of composites can shift from the UV region to the visible light region [31]. Based on the wavelength relationship with the Kubelka-Munk factor in Figure 3, the results show that photocatalyst of $\mathrm{ZnO}$, ${ }_{0.25} \mathrm{ZnO} / \mathrm{ECB}, 0.45 \mathrm{ZnO} / \mathrm{ECB}$, and $0.6 \mathrm{ZnO} / \mathrm{ECB}$ has an absorption at a wavelength of $378 \mathrm{~nm}, 385 \mathrm{~nm}, 405$ 
$\mathrm{nm}$, and $409 \mathrm{~nm}$ respectively. Light absorption in $X \mathrm{ZnO} / \mathrm{ECB}$ samples increased in the visible light region. This is due to the decrease in the level of electron and hole recombination in the synthesized photocatalyst [38].

Determination of the energy gap is done by making a relationship curve between $(\mathrm{F}(\mathrm{R}) * \mathrm{hv}) 1 / 2$ with energy (hv). The energy gap of $\mathrm{ZnO}, \mathrm{ECB}$, and $\mathrm{ZnO} / \mathrm{ECB}$ photocatalysts can be seen in Figure 4. The energy gap can be seen from linear regression which has a coefficient of determination (R2) 1 or close to 1 . Based on Figure 4, the energy gap value of the ECB sample is cannot be known because the value of R2 of the ECB sample is not close to 1 . In addition, the ECB sample does not include semiconductor materials where the characteristics of the semiconductor are having a certain energy gap.

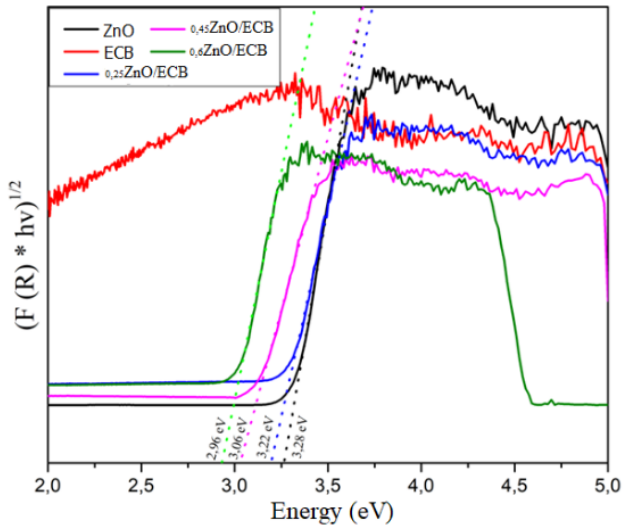

Figure 4. The bandgap energy of $\mathrm{ZnO}, \mathrm{ECB}$, and $\mathrm{XZnO} / \mathrm{ECB}$

The $\mathrm{ZnO}$ photocatalyst has an energy gap of 3.28 $\mathrm{eV}$. The energy gap in the $\mathrm{ZnO} / \mathrm{ECB}$ photocatalyst increased with the increasing concentration of $\mathrm{ZnO}$ in the ECB. Photocatalyst $0.25 \mathrm{ZnO} / \mathrm{ECB}$ has an energy gap of $3.22 \mathrm{eV},{ }_{0.45} \mathrm{ZnO} / \mathrm{ECB}$ has an energy gap of 3.06, while $0.6 \mathrm{ZnO} / \mathrm{ECB}$ has an energy gap of $2.96 \mathrm{eV}$. Synthesized $\mathrm{ZnO} / \mathrm{ECB}$ has lower bandgap energy compared to $3.28 \mathrm{eV}$ for $\mathrm{ZnO}$ thereby suggesting higher photocatalytic activity for the composite material under UV as well as visible light irradiation $[26,39]$.

Photocatalytic activity tests were carried out on samples of $\mathrm{ZnO}, \mathrm{ECB}$, and $\mathrm{XZnO} / \mathrm{ECB}$ to degrade Reactive Black-5 dye using a UV reactor. In the catalytic activity test of the synthesized photocatalyst, 0.1 gram of the photocatalyst sample was used to degrade $50 \mathrm{~mL}$ of $15 \mathrm{ppm}$ Reactive Black- 5 solution at $\mathrm{pH} 2$. The sample was irradiated for 150 minutes. The results of the degradation of the Reactive Black- 5 solution are shown in Figure 5.

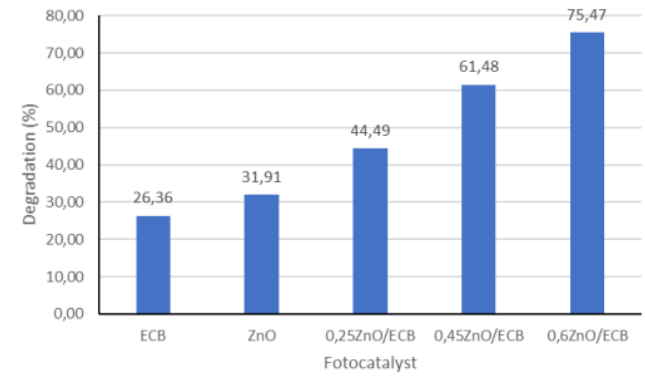

Figure 5 Effect of different photocatalysts on the photocatalytic degradation of Reactive Black-5 dye under UV light irradiation.

Based on Figure 5, the ECB sample was only able to degrade Reactive Black- 5 as much as $26,36 \%, \mathrm{ZnO}$ photocatalyst was able to degrade $31,91 \%$, while the photocatalyst with the highest degradation ability was ${ }_{0.6} \mathrm{ZnO} / \mathrm{ECB}$ with a degradation ability of $75,47 \%$. The photocatalytic activity of $\mathrm{ZnO} / \mathrm{ECB}$ on Reactive Black-5 degradation is better than that of $\mathrm{ZnO}$ photocatalyst and ECB material. This is because the incorporation of biochar with $\mathrm{ZnO}$ causes $\mathrm{ZnO}$ to be dispersed on the surface of the biochar causing a larger surface area of the photocatalyst. The larger the surface area of the photocatalyst, the higher the photocatalytic activity [40]. The high photocatalytic activity of $\mathrm{ZnO} / \mathrm{ECB}$ can also be seen from the energy gap value of the $\mathrm{ZnO} / \mathrm{ECB}$ photocatalyst. Among the $\mathrm{ZnO}$, ECB, and $\mathrm{ZnO} / \mathrm{ECB}$ photocatalyst samples, $0.6 \mathrm{ZnO} / \mathrm{ECB}$ photocatalyst has the lowest energy gap value, which is $2.96 \mathrm{eV}$. The lower the photocatalyst gap energy, the higher the photocatalytic activity. This is because the low energy gap can open the active site faster than photocatalysts with higher gap energy [30]. This can prevent the electron-hole pair recombination more quickly.

\section{CONCLUSION}

The photocatalyst resulting from synthesized $\mathrm{ZnO} / \mathrm{ECB}$ is a crystalline solid with a hexagonal wurtzite crystal structure with crystal sizes of 20.07 $\mathrm{nm}, 19.23 \mathrm{~nm}$, and $17.23 \mathrm{~nm}$ for ${ }_{0.25} \mathrm{ZnO} / \mathrm{ECB}$, ${ }_{0.45} \mathrm{ZnO} / \mathrm{ECB}$, and $0,6 \mathrm{ZnO} / \mathrm{ECB}$ respectively. The $\mathrm{ZnO} / \mathrm{ECB}$ photocatalyst has a peak at a wavelength of 3400 which indicates a hydroxyl group $(-\mathrm{O}-\mathrm{H})$, a wavelength range of 1000 and $1500 \mathrm{~cm}^{-1}$ shows the vibrations of the $\mathrm{C}-\mathrm{O}$ and $\mathrm{C}=\mathrm{C}$ groups of activated carbon, and a wave region of $400 \mathrm{~cm}^{-1}$ which indicates the vibration of the $\mathrm{Zn}-\mathrm{O}$ group. Based on the results of Kubelka-Munk UV-DRS, the energy gap values of $\mathrm{ZnO},{ }_{0.25} \mathrm{ZnO} / \mathrm{ECB},{ }_{0.45} \mathrm{ZnO} / \mathrm{ECB}$, and ${ }_{0.6} \mathrm{ZnO} / \mathrm{ECB}$ were obtained, respectively: 3,$28 ; 3.22 ; 3.06$; and 2.96 $\mathrm{eV}$. The photocatalytic activity of the synthesized 
catalyst under UV irradiation showed that the $\mathrm{ZnO} / \mathrm{ECB}$ composite photocatalyst had a higher degradation ability than pure $\mathrm{ZnO}$. The high photocatalytic activity of the $\mathrm{ZnO} / \mathrm{ECB}$ catalyst was due to the low energy gap of the $\mathrm{ZnO} / \mathrm{ECB}$ catalyst, thereby reducing the electron and hole recombination rate in the synthesized photocatalyst. Photocatalyst ${ }_{0.6} \mathrm{ZnO} / \mathrm{ECB}$ has the highest photocatalytic activity with degradation efficiency reaching $75,47 \%$ under reaction conditions of $10 \mathrm{ppm}$ Reactive Black-5 concentration, solution $\mathrm{pH}=2$, and contact time of 150 minutes

\section{REFERENCES}

[1] S. Laohaprapanon, J. Matahum, L. Tayo, and S. J. You, "Photodegradation of Reactive Black 5 in a $\mathrm{ZnO} / \mathrm{UV}$ slurry membrane reactor," J. Taiwan Inst. Chem. Eng., vol. 49, pp. 136-141, 2015, doi: 10.1016/j.jtice.2014.11.017.

[2] J. Liu et al., "Response of Trametes hirsuta to hexavalent chromium promotes laccase-mediated decolorization of reactive black 5," Ecotoxicol. Environ. Saf., vol. 205, no. June, p. 111134, 2020, doi: 10.1016/j.ecoenv.2020.111134.

[3] R. Kamaludin, A. S. Mohamad Puad, M. H. D. Othman, S. H. S. A. Kadir, and Z. Harun, "Incorporation of $\mathrm{N}$-doped $\mathrm{TiO} 2$ into dual layer hollow fiber (DLHF) membrane for visible lightdriven photocatalytic removal of reactive black 5," Polym. Test., vol. 78, no. May, 2019, doi: 10.1016/j.polymertesting.2019.105939.

[4] E. J. S. Christy, A. Amalraj, A. Rajeswari, and A. Pius, "Enhanced photocatalytic performance of $\mathrm{Zr}(\mathrm{IV})$ doped $\mathrm{ZnO}$ nanocomposite for the degradation efficiency of different azo dyes," Environ. Chem. Ecotoxicol., vol. 3, no. Iv, pp. 31-41, 2021, doi: 10.1016/j.enceco.2020.10.005.

[5] D. K. Bhatt and U. D. Patel, "Photocatalytic degradation of Reactive Black 5 using Ag3PO4 under visible light," J. Phys. Chem. Solids, vol. 149, no. April 2020, p. 109768, 2021, doi: 10.1016/j.jpcs.2020.109768.

[6] C. S. Miyashiro, G. A. P. Mateus, T. R. T. dos Santos, M. P. Paludo, R. Bergamasco, and M. R. Fagundes-Klen, "Synthesis and performance evaluation of a magnetic biocoagulant in the removal of reactive black 5 dye in aqueous medium," Mater. Sci. Eng. C, vol. 119, no. December 2019, p. 111523, 2021, doi: 10.1016/j.msec.2020.111523.
[7] H. A. Begum, A. K. Mondal, and T. Muslim, "Adsorptive Removal of Reactive Black 5 from Aqueous Solution using Chitin Prepared from Shrimp Shells," Bangladesh Pharm. J., vol. 15, no. 2, pp. 145-152, 2012, doi: 10.3329/bpj.v15i2.12580.

[8] M. M. Felista, W. C. Wanyonyi, and G. Ongera, "Adsorption of anionic dye (Reactive black 5) using macadamia seed Husks: Kinetics and equilibrium studies," Sci. African, vol. 7, p. e00283, 2020, doi: 10.1016/j.sciaf.2020.e00283.

[9] K. Tanji et al., "Fast photodegradation of rhodamine $\mathrm{B}$ and caffeine using $\mathrm{ZnO}$ hydroxyapatite composites under UV-light illumination," Catal. Today, no. June, pp. 0-1, 2020, doi: 10.1016/j.cattod.2020.07.044

[10] P. Singh, P. Shandilya, P. Raizada, A. Sudhaik, A. Rahmani-Sani, and A. Hosseini-Bandegharaei, "Review on various strategies for enhancing photocatalytic activity of graphene based nanocomposites for water purification," Arab. J. Chem., vol. 13, no. 1, pp. 3498-3520, 2020, doi: 10.1016/j.arabjc.2018.12.001.

[11] S. Mozia, "Photocatalytic membrane reactors (PMRs) in water and wastewater treatment. A review," Sep. Purif. Technol., vol. 73, no. 2, pp. 71-91, 2010, doi: 10.1016/j.seppur.2010.03.021.

[12] A. Caroline, A. De Souza, and M. G. Ghislandi, "Journal Pre-proof," pp. 0-44, 2021, doi: 10.1016/j.envadv.2021.100064.

[13] A. N. Shafawi, R. A. Mahmud, K. Ahmed Ali, L. K. Putri, N. I. Md Rosli, and A. R. Mohamed, "Bi2O3 particles decorated on porous g-C3N4 sheets: Enhanced photocatalytic activity through a direct Z-scheme mechanism for degradation of Reactive Black 5 under UV-vis light," J. Photochem. Photobiol. A Chem., vol. 389, p. 112289, 2020, doi: 10.1016/j.jphotochem.2019.112289.

[14] R. Shashanka, P. Taslimi, A. C. Karaoglanli, O. Uzun, E. Alp, and G. K. Jayaprakash, "Photocatalytic degradation of Rhodamine B ( $\mathrm{RhB}$ ) dye in waste water and enzymatic inhibition study using cauliflower shaped $\mathrm{ZnO}$ nanoparticles synthesized by a novel One-pot green," Arab. J. Chem., p. 103180, 2021, doi: 10.1016/j.arabjc.2021.103180.

[15] Y. Hanifehpour, N. Hamnabard, B. Khomami, S. W. Joo, B. K. Min, and J. H. Jung, "A novel 
visible-light Nd-doped CdTe photocatalyst for degradation of Reactive Red 43: Synthesis, characterization, and photocatalytic properties," J. Rare Earths, 2016, doi: 10.1016/S10020721(14)60576-7.

[16] A. Noruozi and A. Nezamzadeh-Ejhieh, "Preparation, characterization, and investigation of the catalytic property of $\alpha$-Fe2O3-ZnO nanoparticles in the photodegradation and mineralization of methylene blue," Chem. Phys. Lett., vol. 752, no. May, p. 137587, 2020, doi: 10.1016/j.cplett.2020.137587.

[17] J. R. Kim and E. Kan, "Heterogeneous photocatalytic degradation of sulfamethoxazole in water using a biochar-supported $\mathrm{TiO} 2$ photocatalyst," J. Environ. Manage., 2016, doi: 10.1016/j.jenvman.2016.05.016.

[18] Y. Xue et al., "Hydrogen peroxide modification enhances the ability of biochar (hydrochar) produced from hydrothermal carbonization of peanut hull to remove aqueous heavy metals: Batch and column tests," Chem. Eng. J., vol. 200202, pp. 673-680, 2012, doi: 10.1016/j.cej.2012.06.116.

[19] J. C. Colmenares, R. S. Varma, and P. Lisowski, "Sustainable hybrid photocatalysts: Titania immobilized on carbon materials derived from renewable and biodegradable resources," Green Chemistry. 2016, doi: 10.1039/c6gc02477g.

[20] Mulyatun, "Synthesis of Eichhornia crassipes Biochar: Sustainable Efficient Adsorbent for Reducing Cr (VI) Metal Ion,” J. Phys. Conf. Ser., vol. 1539, no. 1, 2020, doi: 10.1088/1742$6596 / 1539 / 1 / 012003$.

[21] J. N. Nigam, "Bioconversion of water-hyacinth (Eichhornia crassipes) hemicellulose acid hydrolysate to motor fuel ethanol by xylosefermenting yeast," J. Biotechnol., vol. 97, no. 2, pp. 107-116, 2002, doi: 10.1016/S01681656(02)00013-5.

[22] S. M. Yakout and G. Sharaf El-Deen, "Characterization of activated carbon prepared by phosphoric acid activation of olive stones," Arab. J. Chem., vol. 9, pp. S1155-S1162, 2016, doi: 10.1016/j.arabjc.2011.12.002.

[23] M. Danish et al., "Optimization of banana trunkactivated carbon production for methylene bluecontaminated water treatment," Appl. Water Sci., vol. 8, no. 1, pp. 1-11, 2018, doi: 10.1007/s13201-018-0644-7.

[24] P. Raizada et al., "Solar photocatalytic activity of nano-ZnO supported on activatedcarbon or brick grain particles: Role of adsorption in dye degradation," Appl. Catal. A Gen., vol. 486, pp. 159-169, 2014, doi: 10.1016/j.apcata.2014.08.043.

[25] C. G. Joseph, Y. H. Taufiq-Yap, and V. Krishnan, "Ultrasonic assisted photolytic degradation of reactive black 5 (RB5) simulated wastewater," ASEAN J. Chem. Eng., vol. 17, no. 2, pp. 37-50, 2017, doi: 10.22146/ajche.49554.

[26] K. Micheal et al., "Environmental friendly synthesis of carbon nanoplates supported $\mathrm{ZnO}$ nanorods for enhanced degradation of dyes and organic pollutants with visible light driven photocatalytic performance," J. King Saud Univ. - Sci., vol. 32, no. 1, pp. 1081-1087, 2020, doi: 10.1016/j.jksus.2019.10.003.

[27] S. Kamel, H. Abou-Yousef, M. Yousef, and M. El-Sakhawy, "Potential use of bagasse and modified bagasse for removing of iron and phenol from water," Carbohydr. Polym., vol. 88, no. 1, pp. 250-256, 2012, doi: 10.1016/j.carbpol.2011.11.090.

[28] M. Sivakumar, M. Sakthivel, and S. M. Chen, "Activated carbon - $\mathrm{ZnO}$ nanocomposite for electrochemical sensing of acetaminophen," Int. J. Electrochem. Sci., vol. 11, no. 10, pp. 83638373, 2016, doi: 10.20964/2016.10.51.

[29] J. Chen, X. Wen, X. Shi, and R. Pan, "Synthesis of zinc oxide/activated carbon nano-composites and photodegradation of rhodamine B," Environ. Eng. Sci., vol. 29, no. 6, pp. 392-398, 2012, doi: 10.1089/ees.2010.0260.

[30] M. Mian and G. Liu, "Recent progress in biocharsupported photocatalysts: synthesis, role of biochar, and applications," R. Sciety Chem., vol. 8, pp. 14237-14248, 2018, doi: $10.1039 / \mathrm{c} 8 \mathrm{ra0} 2258 \mathrm{e}$.

[31] M. Mian and G. Liu, "RSC Advances photocatalysts : synthesis , role of biochar , and," pp. 14237-14248, 2018, doi: $10.1039 / \mathrm{c} 8 \mathrm{ra02258 \textrm {e }}$.

[32] H. Bel, S. Ben, P. Da, M. Ben, and M. Elena, "Applied Clay Science Photocatalytic decolorization of cationic and anionic dyes over $\mathrm{ZnO}$ nanoparticle immobilized on natural 
Tunisian clay,” Appl. Clay Sci., no. April, pp. 01, 2017, doi: 10.1016/j.clay.2017.11.008.

[33] A. Kumar and H. M. Jena, "Preparation and characterization of high surface area activated carbon from Fox nut (Euryale ferox) shell by chemical activation with H3PO4," Results Phys., vol. 6, pp. 651-658, 2016, doi: 10.1016/j.rinp.2016.09.012.

[34] R. H. Hesas, A. Arami-niya, W. Mohd, A. Wan, and J. N. Sahu, "Preparation and Characterization of Activated Carbon," vol. 8, pp. 2950-2966, 2013.

[35] R. Suntako, "Effect of zinc oxide nanoparticles synthesized by a precipitation method," vol. 38 , no. 4, pp. 1033-1038, 2015.

[36] X. Han and J. Harris, "Synthesis of porous zincbased / zinc oxide composites via sol - gel and ambient pressure drying routes," pp. 8170-8179, 2018, doi: 10.1007/s10853-018-2138-2.

[37] S. Y. Purwaningsih and S. Pratapa, "Nano-sized $\mathrm{ZnO}$ powders prepared by co- precipitation method with various $\mathrm{pH}$ Nano-sized $\mathrm{ZnO}$
Powders Prepared by Co-precipitation Method with Various pH," vol. 020063, no. April 2016, pp. 1-7, 2020, doi: 10.1063/1.4945517.

[38] A. Malathi, P. Arunachalam, A. N. Grace, J. Madhavan, and A. M. Al-Mayouf, "A robust visible-light driven BiFeWO 6 /BiOI nanohybrid with efficient photocatalytic and photoelectrochemical performance," Appl. Surf. Sci., vol. 412, pp. 85-95, 2017, doi: 10.1016/j.apsusc.2017.03.199.

[39] M. Vinayagam, S. Ramachandran, V. Ramya, and A. Sivasamy, "Photocatalytic degradation of orange $\mathrm{G}$ dye using $\mathrm{ZnO} /$ biomass activated carbon nanocomposite," J. Environ. Chem. Eng., vol. 6, no. 3, pp. 3726-3734, 2018, doi: 10.1016/j.jece.2017.06.005.

[40] H. Slimen, H. Lachheb, S. Qourzal, A. Assabbane, and A. Houas, "The Effect of Calcination Atmosphere on The Structure and Photoactivity of $\mathrm{TiO} 2$ Synthesized through an Unconventional Doping using Activated Carbon,” J. Environ. Chem. Eng., pp. 1-8, 2015, doi: 10.1016/j.jece.2015.02.017. 